\title{
The challenge to marine biology in a changing world: future perspectives, responsibility, ethics
}

\author{
E. Mann Borgese \\ Dalhousie University, International Ocean Institute; P. O. Box 524, Valleta, Malta
}

To talk to you oceanographers here about the importance of oceanography today would be like taking owls to Athens or coal to Newcastle. What I would like to draw your attention to here today are the implications, the consequences of the fundamental importance we all know oceanographic research has assumed today.

Let me begin by pointing out that the drafters of the United Nations Convention on the Law of the Sea were aware of this importance as well. It would be hard to explain otherwise why almost one third - about a hundred articles of the 320 of the body of the Convention - touch in one way or another on the oceanographic and environmental sciences and on science-based technology. The Convention is in fact the first body of international law that establishes a regime for the conduct of marine scientific research which, until 1982, had been treated as an implicit freedom of the high seas. Parts XII, XIII, and XIV of the Convention are some of the important innovations introduced by this Convention.

Let us look at some of the main features of this regime for the conduct of marine scientific research.

It has been called a "consent regime", because - while previously there had been unrestricted freedom of exploration and research (to be reminded of this glorious period of oceanography, you should re-read the records of the Her Majesty's Research Vessel "The Challenger" of 120 years ago, and you will realize the total freedom with which those scientists, or "philosophers", as they were called, roamed the seven seas and were received as honoured guests everywhere) - today, as we know, large and important parts of the oceans fall under national jurisdiction, and if you want to do research in these areas, you need the "consent" of the coastal State or host State.

Now this regime, like any regime, has its positive and its negative aspects. It can be used, and it can be misused or abused.

The negative aspect is that a restriction on the freedom of research is a restriction on research and, therefore, negative. Many scientists feared that the consent provisions would entail long and prohibitive bureaucratic procrastinations, costing money and time - which is money.

However, it appears that, on the whole, these fears have not materialized.

The Convention in fact assumes that consent will not be witheld, except in very exceptional and well-defined circumstances: (1) only in the case that the research has military or industrial purposes; (2) that it requires drilling or the use of explosives or the 
erection of installations or artificial islands; or, (3) that the researcher State has provided wrong or inadequate information about the project or has not fulfilled its obligations as on previous occasions. These obligations consist of having scientists of the host state on board the research ship, and the sharing of results and samples, and publication of the results. These, certainly, are not crippling conditions.

On the positive side, the Convention stresses above all the duty to cooperate.

It mandates cooperation between researcher state and coastal state which should facilitate the transfer of scientific knowledge and information. It should encourage researcher states to engage in projects which are of interest not only to the researcher state, but to the coastal state as well. It encourages partnership and participation - where a coastal state has reached a sufficient level of skill and knowledge to be capable of such partnership and participation; it encourages training and assistance in the building of a scientific infrastructure, where the coastal state has not yet reached this stage of development.

The Convention mandates cooperation not only at the bilateral level, but at the regional and global level as well.

At the regional level, it mandates the establishment of regional centres for the advancement of marine science and technology, and spells out the tasks and functions of these centres in some detail.

We shall return to these Centres later.

At the global level, the Convention mandates cooperation between the "competent international organisations", that is, IOC, FAO, UNEP, the WMO, and the new International Seabed Authority - to assist developing countries in their capacity to build up the sciences.

The Convention encourages the internationalisation of science: research projects which have been adopted by a "competent international organisation" need no further consent from the host state, if the host state is a member of the international organisation and did not object to the project at the time it was adopted. One could thus imagine IOC developing into a sort of clearing house for research projects: guaranteeing to coastal States that the research has no military or resource inplications, and needs no further screening or approval.

The Convention assigns a new role to marine scientists in the peaceful settlement of disputes: it establishes a system of "special arbitration", where IOC is mandated to keep a roster of scientific experts who may be called upon to form an arbitral tribunal to make decisions on cases involving scientific issues: a highly innovative procedure!

Most interestingly, the Convention reserves marine scientific research "exclusively for peaceful purposes", just as it reserves the international Seabed and the High Seas for exclusively peaceful purposes and for peaceful purposes, respectively. The real significance of these articles is not yet quite clear and will have to be elaborated by international lawyers over the next years or decades.

So much for the Convention regime; and I mention it, because it is the first one. The Law of the Sea Convention is innovative in so many respects; also with regard to the environment which, in every case, involves science, and in most cases, the marine sciences.

The Convention contains in fact the only existing comprehensive international environmental law, covering pollution from land-based and atmospheric, as well as 
oceanic, sources. It is the only existing legal instrument that effectively integrates the protection of the environment and economic development: development of living and nonliving resources; development of science and technology; and development of human resources; it is the only existing legal instrument that imposes mandatory peaceful settlement of disputes involving environmental issues. The Law of the Sea Convention, as a matter of fact, is still far ahead of the results of the major conference on Environment and Development in Rio last June, which can only build on what the Law of the Sea Conference has already accomplished.

The UNCLOS process is thus now interacting with the UNCED process, and the whole of this must be examined in the broader context of the restructuring of the United Nations system as a whole.

And in this broader context, some fundamental questions have to be asked with regard to science and scientists in general, and the marine sciences and scientists in particular, and as a case study, as it were.

What has happened, over the past half-century since the end of World War II, is that scientific information has become a basic and necessary element in the making of almost any political decision: this is obvious in the case of the environment, but since we know today that economic development must be integrated with the conservation of the environment in which it takes place, scientific information is basic for economic planning and decision-making as well. Economic growth, furthermore, depends 85 or even 90 percent on technological innovation which is based on scientific research. Thus the linkages between science and economic development are fundamental. The same, of course, goes for the linkages between science and defence. The number of scientists working in the defence industry has been growing exponentially during the past decades, and scientists will be needed for the conversion of military establishments for peaceful purposes; for monitoring and surveillance and enforcement.

This fundamental importance of science and scientists for public life, for the conservation of the environment, for economic development, and for peace and security has three major implications.

First of all, it puts a tremendous intellectual, ethical and civic responsibility on the scientist. There is no more ivory tower to shield them.

Is science able - will it ever be able - to deliver the answers to questions which must be answered for sound political decisions to be made?

There is a lot to be modest about! Even a simple case study in the marine sciences, for instance, stock assessment, would encourage us to be modest. As knowledge increased, as fisheries biologists passed from linear projections of single species statistics, to a deeper understanding of multi-species relationships and the interaction of man-made and natural causes, involving chemistry, hydrology, meteorology, ocean-atmosphere interaction, etc., I think we came to the conclusion that stock assessment will always include a considerable uncertainty factor, and that stock management will always remain, to a certain extent, the management of uncertainty. Science can reduce uncertainty, but not eliminate it. And this of course applies to the big issues, such as global warming, as well.

To manage uncertainty in the case of climate and possible climatic change may require, at times, a precautionary approach, that is, not to do rather than do, in case of doubt, but this may not always be productive or acceptable - as it may slow down 
economic development where economic development is the first priority. Another approach is to follow directions which enhance economic development (and therefore should have been followed in any case) while, at the same time, also mitigating environmental impacts.

The best example I can think of is energy efficiency.

Energy is basic for economic development. So much so, that the amount of energy consumption used to be a most reliable indicator of economic growth. This is no longer so. With new technologies, economic growth is overwhelmingly - in the most advanced countries, up to 80 or 90 percent - achieved through energy efficiency, not through additional energy input. As a matter of fact, the figures are rather staggering: Japan, the most advanced country, requires an equivalence of $15 \mathrm{~kg}$ oil to produce $\$ 100$ of GNP. China, in this respect still a developing country, requires a $161 \mathrm{~kg}$ oil equivalency to produce the same amount of GNP. (Incidentally, the Federal Republic of Germany is the second best country in the world ...) Now just imagine the financial savings, the "energy dividend" that can be generated by a developing country if it plans its industrialisation process following the Japanese rather than the Chinese model! At the same time, obviously, greater energy efficiency serves to reduce the $\mathrm{CO}_{2}$ emissions which we should reduce precautionarily, even though there is a great deal of uncertainty with regard to the rate, and the degree, of global warming. Investment in energy efficiency is a classic example for the integration of environment and development which most of us most of the time don't yet know how to conceptualize. Much of the time, we think of conservation of the environment as a constraint on economic development: as a limit; we think in dualistic terms: development, here; environment, there, and our institutional frameworks, our planning and decision-making structures reflect this dualistic approach. As long as we cannot free ourselves from this worldview, it will be difficult to improve the present situation.

In a way, this has been a parenthesis. Let me return to the role of the scientist. Clearly, no such development is possible except on the basis of scientific information. The scientist must be there.

This leads me to the second major issue that I see arising from this growth in the social and economic importance of science: and that is, the tremendous unevenness in the distribution of science and scientists. Fairly recent statistics (by UNCTAD, UNIDO, and UNESCO) indicate that about 90 percent of all scientific research, and research and development, is carried out in developed countries: the research gap between "North" and "South" is the worst of all development gap. India and China have taken giant steps forward. They are training huge numbers of scientists, which will quickly alter the UNCTAD statistics: they will not alter the real situation in most developing countries, however - especially in Africa, and in the rest of Asia, and most of Latin America as well. Without the ability to conduct scientific research and industrial research and development, developing countries simply cannot develop; and they are in danger of increasing marginalisation, especially since the new phase of the industrial revolution in the "North" - through miniaturization, dematerialization, automation and robotization - is cancelling out the so-called comparative advantage of cheap raw materials and cheap labour, which is simply no longer needed.

What can be done to strengthen the scientific capacity of developing countries.

As I pointed out at the beginning, the Law of the Sea Convention is the most 
advanced legal and institutional framework for scientific cooperation, for the strengthening of scientific infrastructure in developing countries and for the "transfer" of technology - if we decide to use it and to build on it.

A number of steps must, and can, be taken:

First of all, it will be necessary to convince the leaders in the poor countries that science and science-based high technology are not luxuries, to be pursued after "basic needs" have been satisfied, but that science and technology today is the very basis of economic development which simply will not take place without scientific capacity. Many leaders in many countries are not yet at all convinced of that and, obviously, when you go to a country like Somalia, it is difficult to even try to do convincing of this sort at this point. Minister Jan Pronk of the Netherlands has just returned from Somalia. He is a strong man, but he is human. When he gave his report in Parliament, he burst into tears. Such is the human tragedy in that country. Obviously you can't talk to the Somalis today about science and high technology. What they need is crisis management. But we have to look beyond crisis management, to prevent the recurrence of the crisis. And this requires scientific capacity.

Once the first step has been taken, and the leaders of developing countries are convinced of the fundamental importance of science and technology, the second step can be taken: they must build their own, national, scientific infrastructure. Without that, no amount of international cooperation can be effective. The Third World Academy of Science has recommended that every developing country, even the poorest, should earmark a certain percentage of its educational budget (however small that budget may be) to the teaching of science, to scientific research, and to applied research and development, as much as ten or 15 percent. That would be a start. It is only on this basis that international cooperation makes any sense. It is on this basis that regional cooperation can be initiated, through the establishment of regional centres of excellence. Oceanography is an expensive science. A small, developing country may not be able to afford an oceanographic institution. A group of countries together, however, may well afford what no single country can afford alone. This is true in Europe: it is even more true in regions of developing countries. A lot of science and technology can be developed on the basis of South-South cooperation.

South-South cooperation, while essential, need not be carried out to the exclusion of North-South cooperation, which is equally important and can be conducted bilaterally or multilaterally, through international institutions. A very interesting recent example is the Training Programme - established by the Pioneer Investors in seabed mining, under the aegis of the Preparatory Commission for the International Seabed Authority and for the International Tribunal for the Law of the Sea - where China, France, India, Japan, the Russian Federation and a multinational company consisting of formerly socialist States, called Interocean Metal Joint Organisation, have assumed the responsibility for the training of a number of scientists and technicians from developing countries, for one or two year stretches, in the areas relating to deep-sea exploration and exploitation.

At this time of economic recession, not to say, depression, it is obviously difficult to find financial means for the establishment of regional centres of excellence. New sources, new ways of financing such undertakings, are urgently needed.

The International Ocean Institute has done quite a bit of work on this subject, including a feasibility study for the establishment of a Mediterranean Centre for Research 
and Development in Marine Industrial Technology, which should enhance both SouthSouth and North-South cooperation in marine science and technology.

Our approach is based on the awareness that high technology is basically, qualitatively different from traditional technology: that it is soft-ware oriented; that it is information- and knowledge based; that therefore you cannot "buy" it, you must learn it.

Now, if technology is basically different, so will be "technology transfer". The transfer of high technology, we concluded, can be best achieved, or is perhaps only achievable through joint technological development or technological co-development. And thus we recommended the opening of new systems such as EUROMAR and EUREKA to the South; or, probably more suitably, the establishment of mechanisms, based on the same principles of joint R\&D financed through international, private/public cooperation, South-South and North-South, through regional centres, or rather, systems or networks. The idea really caught on: President Perez in Venezuela picked it up in his "Project Bolivar" which is just an adaptation of EUREKA to the Latin American and Caribbean setting; and we proposed the establishment of Technocaribe as a subsystem of Project Bolivar, the way Euromar is a subsystem of Eureka.

Venezuela is in some trouble today, and this means a setback for Project Bolivar which had been launched with great promise and generous support from the Interamerican Development Bank. But I think Colombia will take up the challenge now; and this, in any case, is the way of the future and of implementing the two paragraphs in the Law of the Sea Convention which mandate the establishment of regional centres.

If we have to convince the leaders of the developing countries of the fundamental importance of science and technology, we have to convince the industrial and political leaders of the "North" that it is in their own best interests to share the development of new high technologies with the "South".

Not only is this mandatory in broad areas of high technology, if we are serious about "sustainable development" and the conservation of the global ecosystem: I should like to point out that the efforts in GATT to tighten intellectual property rights and the efforts at UNCED to facilitate technology "transfer" are diametrically opposed. If GATT wins, the environment loses. But GATT cannot win, because (and this is my second point) -

The sharing of high technology is not only necessary, it is inevitable, due to the very nature of this technology, which is knowledge based; and knowledge will recognize no frontier: it is just a question of a little time. Technology today is "stolen" to the tune of billions of dollars a year; and if we do not design new ways of fair development sharing probably best through new joint ways of financing joint research and development these figures are bound to rise: more and more will be "stolen".

Thirdly, the sharing of technology will, first of all, reduce the cost of R\&D to the industrialized countries, by as much as 50 percent if the participation of developing countries in R\&D as equal partners is paid for; secondly, it will reduce risk, by spreading it wider, and, thirdly, it will create new and bigger markets.

These would be the arguments to convince the industrialized countries to move in the direction of technology cooperation in the post-UNCED era.

Now I come to my final point: if the importance of the scientist in public life, in economic development, in the conservation of the biosphere, in national and international security, is as crucial at it is, responsibility should imply a commensurate amount of influence and power: that is, the role of the scientist can no longer be purely advisory - 
suggesting that his/her advice may be followed or ignored, as, alas has happened in so many cases - but that the scientist must be involved in decision-making, and this brings up two major issues.

The first is, to examine this development from the point of view of the scientist. How compatible are politics and science from his/her point of view?

The second is to examine what institutional mechanisms are required to facilitate the participation of scientists in decision-making.

On the first question: who is the scientist who can, or wants to, take precious time from his work at the lab to devote it to political issues, attending of meetings, listening to incomprehensible positions, etc.? Efforts, even within scientific research institutions, to respond to the challenge of the new ethical and political responsibilities of the scientist, with the establishment of interdisciplinary "policy" programmes where social and natural scientists would work together on the new type of questions, have not always met with success. I remember the case of one highly prestigious research institute in California where the effort had to be dropped because the scientists could not be lured away from their labs. Other cases, like, for example, Woods Hole Oceanographic Institution, have been more successful.

We need to convince scientists that they do have new ethical and civic responsibilities and that they have to integrate these into their traditional ones.

In his last major piece of work, before his death, the great oceanographer and humanist Roger Revelle, wrote:

"In spite of the breadth and depths of its interests, the Institution (he was writing about Scripps), in my opinion, is not broad enough. Though the staff deals with many problems of great concern to human beings, the human dimensions are pretty much left out of the picture. A greater effort in both research and teaching is needed on the ways in which human beings and their institutions interact with the oceans and their living inhabitants. These interactions are the basis of government policies concerning the ocean realm at all levels of government, from the United Nations to local municipalities. To become a more useful institution to the larger society, Scripps needs to add to its staff some faculty and research staff members who will be able to develop a deeper understandig of how ocean policies can be formulated, implemented, and changed."

This, of course, applies to all scientific research institutions as it does to Scripps.

Now to the second question: how could government systems, whether local, national, or international, be organized so as to include scientists in the decision-making processes?

Should scientists run to become Members of Parliament, a position thus far reserved for lawyers and, occasionally, economists? To have to run for Parliament, for Congress, to become a politican, would probably be the end of the scientist as a scientist; (incidentally, a study of the professional backgrounds of parliamentarians and politicians over the past few hundred years is extremely interesting and revealing. In Europe, literature and poetry, and music are well represented, which reflects the high regard in which the arts are held in Europe. Science, on the whole, is absent).

The most interesting model that I have come across with regard to the participation of scientists in decision-making, was the Yugoslav Constitution of 1958. The Yugoslav Parliament was a rotating multi-chamber system. There was one chamber, the political 
chamber, which was the fulcrum of the system. An affirmative vote of that chamber was required for any decision. But then there was a chamber of enterprises (managers and workers); there was a chamber of public health (representatives of hospitals, doctors nurses), and there was a chamber of scientists. Now, any decision that required an input from the medical profession and/or affected the public health system, needed an affirmative vote by that chamber as well; any decision requiring a scientific input or affecting the science community of the country, required an affirmative vote by the chamber of scientists together with the political chamber. The scientists were represented through their institutions, and it was within these institutions that the scientists reached their own decision.

Now, as you know, the United Nations system, after 50 years, is undergoing a process of restructuring, to respond to all the dramatic changes that have taken place during this last half century. This effort should culminate in San Francisco in 1995. It should draw on the institutional consequences of the Rio Conference which, in turn, must build on the institutional results of the United Nations Conference on the Law of the Sea.

It might be worth your while to look into this decision-making model.

If scientific institutions, like Scripps, follow Roger Revelle's advice, and build policy issues into their structures, we can begin to build from the bottom up.

If we utilize this moment of restructuring the United Nations system - whose structure always will reflect, and must somehow match, the structures within national government - we can begin to build from the top down. It is a very challenging, and very exciting moment as far as science is concerned.

Science and scientists must not let this moment pass without making their particular contribution. 